\title{
ОГЛЯДИ
}

УДК: 616.37-091.8-02:616.379-008.64-084

doi:10.25128/2078-2357.19.3.10

${ }^{1}$ Х. І. КУРИЛО, ${ }^{1}$ А. С. ВОЛЬСЬКА, ${ }^{1}$ І. М. КЛІщ, ${ }^{2}$ Б. В. ЗАБЛОЦЬКИЙ

${ }^{1}$ Тернопільський національний медичний університет імені І. Я. Горбачевського МОЗ України майдан Волі 1, Тернопіль, 46002

${ }^{2}$ Тернопільський національний педагогічний університет ім. Володимира Гнатюка вул. М. Кривоноса, 2, Тернопіль, 46027

e-mail: kurylokh@tdmu.edu.ua

\section{СУЧАСНІ ПІДХОДИ ДО ФАРМАКОЛОГІЧНОЇ КОРЕКЦІЇ МЕТАБОЛІЧНИХ ЗРУШЕНЬ ПРИ ЦУКРОВОМУ ДІАБЕТІ ТИПУ 2}

Проведено аналіз і систематизацію даних літератури щодо фармакологічної корекції метаболічних порушень при цукровому діабеті типу 2. Використано методи інформаційного пошуку, аналізу даних літератури щодо дослідження лікарських рослин 3 гіпоглікемічною дією. Розглянуто лікарські рослини та природні амінокислоти, які володіють гіпоглікемічною дією та можуть використовуватись 3 лікувально-профілактичною метою у хворих 3 цукровим діабетом типу 2. Встановлено, що біологічно активні компоненти лікарських рослин можуть впливати на активність ключових ферментів обміну вуглеводів, транспорт глюкози та функції рецептора до інсуліну, порушення яких відіграють важливу роль в патогенезі цукрового діабету.

Ключові слова: иукровий діабет, козлятник лікарський, чорниця звичайна, таурин, гіпоглікемічна активність.

Цукровий діабет (ЦД) визнано однією з найбільших медико-соціальних проблем в Україні та світі, оскільки він зумовлює високий ризик розвитку інвалідизуючих ускладнень і підвищену смертність населення [1]. Згідно з даними ВОО3, кількість хворих щороку зростає і вражає людей незалежно від віку, статі та достатку, що зумовлює підвищення смертності в 3-4 рази та скорочує тривалість життя на 20-30\% [31].

У патогенезі ЦД типу 2 ключову роль відіграє порушення секреції інсуліну $\beta$-клітинами та периферичної утилізації глюкози. Порушення синтезу інсуліну може проявлятися зміною послідовності амінокислот в його молекулі та перетворення проінсуліну в інсулін. В обох випадках виробляється гормон, який матиме низьку біологічну активність, що приведе до розвитку гіперглікемії.

Метою лікування пацієнтів 3 ЦД типу 2 є досягнення максимального зниження сумарного ризику розвитку ускладнень шляхом досягнення та підтримання цільового рівня показників обміну речовин [8, 9].

Таким чином, множинність ланок патогенезу ЦД та його ускладнень при цій патології потребує використання для їх профілактики та лікування препаратів 3 різними фармакологічними властивостями. Одним з таких засобів подібної дії $є$ препарати на рослинній основі.

Прогностичні оцінки експертів ВООЗ свідчать про актуальність проблеми ЦД типу 2, бо ЦД є хронічним захворюванням, при якому необхідно враховувати низку чинників щодо 
кожного окремого випадку, що може позитивно чи негативно впливати на кінцевий результат лікування [15].

Згідно міжнародних рекомендацій, лікування ЦД повинно включати як немедикаментозні, так і медикаментозні методи.

Стандартні схеми медикаментозного лікування пацієнтів з ЦД обох типів широко представлені у спеціальній літературі, регулярно доповнюються та оновлюються відповідно до вимог доказової медицини [28].

Основними завданнями медикаментозного лікування пацієнтів з ЦД є попередження гострих ускладнень захворювання.

Препаратом першої лінії на сьогодні є похідні сульфонілсечовини та бігуанідів. Препарати сульфонілсечовини II покоління використовуються в клінічній практиці з 60-х років, на цей час $є$ найбільш вживаними пероральними цукрознижуючими препаратами [33].

Крім традиційних груп цукрознижуючих пероральних засобів $[16,22]$, на сьогодні застосовують такі групи, як засоби, що потенціюють секрецію інсуліну - GLP-1 і ЖIП глюкозозалежний інсулінотропний пептид; антагоністи альфа-рецепторів, похідні імідазолу, мідаглізол; карбоксимідаліди; інсулін-міметичні речовини; препарати, що посилюють метаболізм глюкози незалежно від інсуліну; речовини - потенціатори дії інсуліну: глітазони циглітазон, дарглітазон, троглітазон, енглітазон; фрагменти СТГ людини; інгібітори контрінсулярніх гормонів - аналоги глюкагону, сульфонамідо-бензамід, аналоги соматостатину.

Методи лікування при ЦД можна розділити на кілька груп [28]. Дієтотерапія - зниження споживання легкодоступних вуглеводів, контроль кількості вуглеводної їжі та надання переваги продуктам, що містять харчові волокна. Медикаментозні [10], які застосовують при декомпенсації вуглеводного обміну, і профілактика ускладнень, що здійснюється під час всього перебігу захворювання.

Пероральні цукрознижувальні препарати застосовуються з метою стимуляції секреції $\beta$ клітинами підшлункової залози додаткового інсуліну, 3 метою відновлення нормальної концентрації глюкози в крові.

Похідні сульфонілсечовини, що підвищують секрецію інсуліну бета-клітинами підшлункової залози, $є$ основною групою засобів для лікування ЦД типу 2 , a ïx цукрознижувальна дія пов'язана з прискореням і збільшенням секреції інсуліну, підвищенням його доступності в тканинах, посиленням його дії [22, 33].

Однак до ери відкриття інсуліну (1922 рік) і синтетичних цукрознижувальних препаратів (з середини 50-х років) саме фітотерапія була єдиним методом підтримки хворих. Тому й на сучасному етапі арсенал нових природних препаратів поповнюється завдяки лікарським рослинам [19]. Фітотерапія здатна проявити суттєву підтримку стандартному способу лікування на всіх стадіях захворювання, а деколи й замінити традиційне лікування. Доведено, що пацієнти, які активно використовують фітотерапію, потребують нижчих доз інсуліну і пероральних цукрознижувальних ліків.

У науковій і народній медицині є численні дані про використання лікарських рослин для лікування хворих з ЦД. Відомо понад 150 рослин, що виявляють антидіабетичний ефект [11, 29]. Сьогодні фітотерапія стала важливою складовою частиною лікування хворих на ЦД [19]. Вона може бути застосована як монотерапія у поєднанні з дієтотерапією або як допоміжна - у поєднанні з таблетованими цукрознижуючими препаратами або інсуліном. Така комплексна терапія зумовлює досягнення компенсації захворювання, його стабілізацію, а інколи дозволяє зменшити дозу інсуліну чи таблетованих цукрознижуючих засобів [30].

Механізми гіпоглікемічної дії фітопрепаратів сьогодні активно вивчаються та висунено дослідниками декілька гіпотез: БАР рослин збагачує організм лужними радикалами, які в слабколужному розчині в присутності $\mathrm{Ca}(\mathrm{OH})_{2}$ глюкозу перетворюють на фруктозу або манозу, для засвоєння яких не потрібно інсуліну; цукрознижувальні рослини містять гуанідин, який $\epsilon$ сильною основою і діє подібно до препаратів похідних сульфосечовини [7]; під впливом фітопрепаратів посилюється відновлення $\beta$-клітин в острівцях Лангерганса; здатність рослинних речовин регулювати імунні механізми за допомогою імуномодуляторів. Рослини

72 ISSN 2078-2357. Наук. зап. Терноп. нац. пед. ун-ту. Сер. Біол., 2019, № 3 (77) 
нормалізують вторинні порушення обміну речовин, забезпечуючи профілактику ускладнень 3 боку сітківки очей, печінки, серцево-судинної, сечовидільної, нервової, опорно-рухової та інших систем організму хворого [2].

Основним у лікуванні ЦД є досягнення нормалізації вуглеводного, білкового і жирового обмінів, профілактика та лікування гострих і хронічних ускладнень та їх наслідків, тому обов'язковою умовою фітотерапії $є$ застосування фітопрепаратів з різними механізмами дії. Таким чином можливий одночасний фармакологічний вплив на кілька ланок розвитку хвороби, що дозволить швидше досягнути бажаного результату лікування [27].

Використання рослинної сировини для створення лікарських препаратів пояснюється багатьма причинами. Компоненти, які входять до складу препаратів, завдяки широкому спектру фармакологічної дії та низькій токсичності, проявляють комплексну дію на організм і рідко викликають серйозні побічні реакції. Це дозволяє проводити тривале лікування при хронічних захворюваннях. Діючі речовини, які входять до складу рослин, часто виявляють високу спорідненість до ферментних систем організму і тому відносно легко вступають у метаболічні процеси [21].

У народній та науковій медицині в терапії ЦД використовували природні джерела інуліну [5]: бульби топінамбуру, жоржини, корені цикорію, оману, кульбаби тощо. Як цукрознижуючі засоби використовують лушпиння квасолі, кизил, пагони та листя чорниці, галегу. Ці лікарські рослини потрапляють у різні комбінації лікарських зборів, дієтичних та харчових добавок (офіцінальним збором для лікування та профілактики цукрового діабету $\epsilon$ «Арфазетин») [25].

В Україні лише в 2012 році вперше розпочато випуск вітчизняного препарату «Арфа комбі» (ПАТ «Фармак») [4, 32]. У його склад входять таурин, екстракт перикарпію квасолі, екстракт листя чорниці. Рекомендують препарат до використання в раціонах дієтичного харчування особам, які контролюють рівень цукру крові, як додаткове джерело біологічно активних речовин - інгібіторів альфа-амілази та альфа-глюкозідази, фенольних кислот, таурину 3 метою підтримки нормального вуглеводного обміну. Він знижує розщеплення і засвоєння вуглеводів, що потрапили з їжею.

Фітотерапія при ЦД частково відтворює або посилює ефекти багатьох пероральних антидіабетичних препаратів при можливому зниженні їх побічних ефектів і дози, а також сприяє синтезу інсуліну, оптимізуючи його дію на рівні тканин, стимулює процеси регенерації бета-клітин та покращує роботу усіх ланок імунної системи, нормалізує вторинні порушення обміну речовин і гормонів та забезпечує профілактику ускладнень зі сторони серцево-судинної, сечовидільної систем, опорно-рухового апарату [19, 22, 24, 29].

Значущість лікарських рослин в комплексній схемі лікування ЦД пов'язана 3 тим, що в них оптимальна біодоступність на системному, органному і клітинному рівнях; фізіологічно закладена в організмі біохімічна здатність до засвоєння і ефективної утилізації проміжних i кінцевих продуктів метаболізму, що істотно знижує вірогідності кумуляції, органотропної, алергенної й токсичної дії.

Встановлено, що більшість лікарських рослин справляють олужнюючий ефект і глюкоза у слаболужному середовищі переходить в інші вуглеводи - манозу і фруктозу, для утилізації яких не треба інсуліну, унаслідок чого потреба у введенні останнього знижується.

Препарати та збори із козлятника (галеги лікарської), лушпиння квасолі, листя чорниці оптимізують дію інсуліну в результаті його захисту від активності ферментів. Включення «захищеного» інсуліну в обмінні процеси вирішує проблему гормональної недостатності і нормалізує порушений вуглеводний обмін без негативного впливу на синтез білків і жирів в організмі.

Згідно з прогнозами експертів ВООЗ, у найближчі 10 років частка фітопрепаратів у загальному обсязі споживання фармацевтичних препаратів сягне 70\%. Це пов'язано, з тим, що близько $15 \%$ населення Землі страждає на алергію, у тому числі й на синтетичні лікарські препарати. Європейські країни не тільки імпортують, але й у великому асортименті виробляють лікарські рослини та лікарські засоби рослинного походження. 
Проаналізувавши ряд джерел інформації про лікарські засоби (Державний реєстр лікарських засобів, компендіум, наукові журнали медичного і фармацевтичного профілю, монографії, навчальні книги та ін.), вдалося сформувати групу лікарських засобів рослинного походження з гіпоглікемічною дією, які зареєстровані і мають місце на ринку України.

Сучасний фармацевтичний ринок нашої держави містить близько $15 \%$ фітопрепаратів, які використовуються з лікувально-профілактичною метою при захворюваннях на ЦД.

Одним 3 перспективних шляхів збільшення кількості фітопрепаратів на сучасному фармацевтичному ринку є створення безпечних лікарських комбінацій, що поєднують різні види фармакологічної дії. Нові комбінації створені на основі природних компонентів і містять комплекси біологічно активних речовин, структурно подібних метаболітам організму, мають більш низьку токсичність у порівнянні 3 синтетичними лікарськими засобами, а також проявляють багатогранний вплив на організм людини.

Для профілактики і лікування різних захворювань важливим $є$ вплив лікарських засобів на органи чи тканини, уражених патологічним процесом. Перспективним напрямком $\epsilon$ використання нанотехнологій, що дозволяє оптимізувати ефективність терапії та звести до мінімуму побічні ефекти, поліпшити комплаєнс. Наночастки можуть утворювати комплекси 3 продуктами обміну речовин, лікарськими засобами, покращуючи їх стабільність і розчинність, унаслідок чого ліки краще засвоюються клітинами організму. Досвід народної медицини дає змогу вважати, що під час лікування лікарськими рослинами кращий ефект спостерігається при застосуванні лікарських зборів. Сьогодні на фармацевтичному ринку України відсутні ліпосомальні форми гіпоглікемічних засобів, тому, зважаючи на це, доцільним було створення ліпосомальної форми досліджуваної нами фітокомпозиції Галевіт. Комплексне застосування забезпечує одночасний вплив на декілька систем організму, що, очевидно, матиме позитивний клінічний ефект. Комплекс біологічно активних речовин компонентів збору підвищує толерантність до вуглеводів, підсилює глікогенутворювальну функцію печінки. Тому ми вважаємо доцільним пошук нових цукрознижувальних фітопрепаратів, які б не тільки регулювали обмін вуглеводів, але і позитивно впливали на ліпідний обмін, імунологічний статус. Актуальність даних розробок зумовлена постійним зростанням хворих на цукровий діабет в Україні.

Серед імпортних лікарських засобів для профілактики та лікування цукрового діабету найбільша питома вага належить препаратам 3 Німеччини й Данії. Для розробки нової фітокомпозиції нами було взято до уваги склад фітокомпозицій, що використовуються 3 лікувально-профілактичною метою у хворих на цукровий діабет сьогодні.

Недостатній асортимент антидіабетичних українських ЛЗ у формі таблеток на основі стандартизованих екстрактів листя чорниці звичайної та трави козлятника лікарського зумовлює актуальність розробки складу, технології та методів стандартизації досліджуваної фітокомпозиції.

Фітотерапія повинна бути обов'язковим компонентом у лікуванні діабету. Ряд лікарських рослин попереджають розвиток ускладнень діабету не тільки внаслідок гіпоглікемічного ефекту, але й завдяки зниженню оксидативного стресу, модуляції метаболізму ксенобіотиків, депресії глюконеогенезних ферментів [19, 22]. Незважаючи на доступність та відносну дешевизну вітчизняних фітозасобів, що $є$ дуже важливим, український ринок гіпоглікемічних засобів рослинного походження досить обмежений [29].

3 вище вказаного можна стверджувати, що препарати рослинного походження, які застосовуються у хворих на ЦД, мають різнопланову метаболічну, регуляторну поліорганну дію. 3 іншого боку, у діабетології в останні роки швидко розвивається напрямок із вивчення ролі рослинних препаратів за ЦД типу 2.

Одним 3 основних механізмів гіпоглікемічної дії рослин $є$ стимуляція $\beta$-клітин панкреатичних острівців, які синтезують інсулін. Рослини справляють олужнюючий ефект i глюкоза у слаболужному середовищі переходить в інші вуглеводи - манозу і фруктозу, для утилізації яких не потрібно інсуліну, внаслідок чого потреба у введенні останнього зменшується. Фруктоза, на відміну від глюкози, не приводить до підвищення секреції $\beta$ клітинами інсуліну, можливо, через відсутність на поверхні $\beta$-клітин транспортера фруктози

74 ISSN 2078-2357. Наук. зап. Терноп. нац. пед. ун-ту. Сер. Біол., 2019, № 3 (77) 
(GLUT5). Обмін фруктози в печінці здійснюється гліколітичним шляхом, при якому частина фруктози перетворюється в глюкозу, а інша - в фруктозо-1-фосфат і далі в дігідроксіацетонфосфат, який в подальшому ряді реакцій перетворюється на ліпіди [30]. Це пояснює, яким чином збільшення споживання фруктози прискорює в печінці процеси, що ведуть до синтезу і накопичення жирних кислот та триацилгліцеролів.

Отже, гіпоглікемічна дія біологічно активних компонентів лікарських рослин реалізується декількома шляхами, а саме: завдяки абсорбції глюкози в кишечнику, збільшення секреції інсуліну підшлунковою залозою, інсуліноміметичної дії, інгібування продукції глюкози гепатоцитами або посилення поглинання глюкози периферичними тканинами через вплив на транспортери глюкози (GLUT), модуляції антиоксидантного захисту тощо. Стимулювання периферичного поглинання глюкози в інсулін-чутливих та інсулін-нечутливих тканинах є одним 3 декількох механізмів, які контролюють рівень глюкози в крові, а отже, спрямована дія на цей процес є однією з найперспективніших цілей у лікуванні ЦД.

Увагу науковців насамперед привертають лікарські рослини, які широко використовуються в народній і практичній медицині для лікування ЦД і мають достатню сировинну базу. Тому об'єктом досліджень вибрано надземну частину лікарської рослинної сировини - траву козлятника лікарського.

Козлятник лікарський, галега лікарська (Galega officinalis L), вважається однією 3 найстаріших рослин, що використовуюється у лікуванні ЦД [24]. Активний цукрознижувальний компонент сухого екстракту козлятника лікарського діє за позапанкреатичним механізмом, підвищуючи вміст глікогену в печінці та пригнічуючи активність ферменту інсулінази. Гіпоглікемічний ефект досліджуваного екстракту зумовлений наявністю фітолу, етилового естеру пальмітинової кислоти, фітостеролів, $\alpha$-амірину, похідними хіназоліну або їхньою синергічною дією. Фітол здатний впливати на профіль глюкози, знижуючи глюконеогенез і пригнічуючи синтез глюкози в печінці, а також, мобілізуючи ліпіди м'язів, зумовлює підвищення чутливості їх до дії інсуліну, знижує інсулінорезистентність і регулює метаболічні розлади, що супроводжують діабет шляхом активації RXR (retinoid X receptor), що призводить до посилення експресії гена GLUT2 та мРНК глюкокінази.

У Великобританії, США, Болгарії лікарську рослинну сировину трави козлятника використовують в офіційній медицині на початкових стадіях чи в комплексному лікуванні ЦД, зокрема діабету типу 2.

Гіпоглікемічну дію козлятника лікарського виявлено ще в 1927 році, але наукові факти про цукрознижувальну дію трави і насіння суперечливі. Вважають, що гіпоглікемічний ефект притаманний лише екстрактам [3], які містять алкалоїди (галегін), що пригнічують всмоктування глюкози у шлунково-кишковому тракті. Окрім того, галегін може функціонувати як ліганд до імідазоліновового рецептора I2 (I2R). Зв'язування гуанідинів 3 I2R посилює фосфорилювання цАМФ-активованої протеїнкінази, яка виступає регулятором енергетичного гомеостазу та активує транслокацію GLUT-4 у м'язовій тканині, посилюючи таким чином поглинання глюкози скелетними м'язами.

Основними компонентами галеги лікарської $є$ фітол, етиловий ефір пальмітинової кислоти, фітостероли і $\alpha$-амірин. Фітол шляхом активації RXR рецепторів (retinoid X receptor) зумовлює посилення експресії гена GLUT2 і мРНК глюкокинази і має здатність зменшувати прояви інсулінорезистентності, регулюючи метаболічні розлади, здатний впливати на профіль глюкози, знижуючи глюконеогенез і пригнічуючи їі синтез в печінці, а також мобілізує ліпіди м'язів, спричиняючи підвищення чутливості їх до інсуліну [5], а фітостероли пригнічують адсорбцію холестеролу.

У складі галеги лікарської виявлено низку флавоноїдів. Серед них сім речовин, які $\epsilon$ похідними двох агліконів і цукрових компонентів - глюкози, рамнози і галактози. Виявлено, що лютеолін, який міститься в екстракті галеги лікарської, інгібуює активність $\alpha$-амілази, а флавоноїди сприяють підвищенню концентрації кальцію в крові, який впливає на секрецію інсуліну клітинами підшлункової залози. Гіпоглікемічна дія флавоноїдів обумовлена наявністю фенольного кільця у їхній структурі [19]. Відомо також про позитивний вплив флавоноїдних сполук на функцію нирок, печінки та інших органів.

ISSN 2078-2357. Наук. зап. Терноп. нац. пед. ун-ту. Сер. Біол., 2019, № 3 (77) 
Присутність гуанідинових алкалоїдів в козлятнику лікарському зумовлює пролонговану гіпоглікемічну дію [2]. Лише у разі тривалого його застосування спостерігається стійкий цукрознижувальний ефект. Активний цукрознижувальний компонент галеги має здатність підвищувати вміст глікогену в печінці та пригнічувати активність ферменту інсулінази. Тривалий прийом галеги відновлює активність клітин-острівців Лангерганса, безалкалоїдна фракція попереджає розвиток оксидативного стресу в щурів за умов стрептозотоцинового діабету, забезпечуючи мобілізацію антиоксидантних механізмів захисту системи крові.

Однією 3 рослин, що широко використовується в медицині, $є$ чорниця звичайна (Vaccinium myrtillus L.) [3]. У медичній практиці іiї листя виявляє протидіабетичну активність, C і Р-вітамінну активність [13]. Установлено сприятливий вплив листя чорниці на процеси окисного фосфорилювання в мітохондріях печінки [17]. Хімічний склад листя рослини - це фенольні сполуки, які відповідають за цукрознижувальну діяльність.

Гіпоглікемічна активність сухого екстракту чорниці звичайної обумовлена наявністю у складі сировини простих фенолів (арбутин); поліфенолів, а саме хлорогенової кислоти, що інгібує глюкозо-6-фосфатазу, яка каталізує кінцевий етап глікогенолізу та глюконеогенезу; та флавоноїдів, які поліпшують мікроциркуляцію тканин за рахунок мембраностабілізуючої та антиоксидантної дії і покращують метаболізм інсулінозалежних процесів. За даними фітохімічних досліджень, чорниця містить глікозиди міртилін та неоміртилін («рослинний інсулін») $[6,23,26]$.

Одним із механізмів розвитку діабетичних ангіопатій вважають наявність генетичної схильності до морфофункціональної аномалії клітинних мембран, що реалізується в судинну патологію через метаболічні порушення. У зв'язку з цим доцільним є використання в лікуванні хворих на ЦД лікарських засобів мембраностабілізуючої дії. Одним 3 таких препаратів $\epsilon$ таурин. У даний час доведено, що окремі ефекти таурину пов'язані 3 його участю в окисновідновних реакціях.

Природна амінокислота таурин бере участь у біохімічних перетвореннях, сприяє поліпшенню енергетичних процесів, відіграє суттєву роль в обміні жирів, входить до складу парних жовчних кислот, сприяє емульгуванню жирів у кишечнику. Характерною особливістю таурину $є$ здатність стимулювати репаративні процеси, стабілізувати вуглеводний обмін, знижувати середньодобову глікемію. Різноманітні біологічні властивості таурину визначають широкий спектр його фармакологічної активності. Дефіцит речовини асоційований 3 дисфункцією в різних тканинах, може впливати на патогенез діабетичних судинних ускладнень [34]

В останні роки з'явилися дані щодо ефективності застосування таурину не тільки як гепато-, нейро- і кардіопротектора, а й як засобу для профілактики і лікування ЦД та його судинних ускладнень. В експериментальних дослідженнях установлено, що таурин покращує чутливість периферичних тканин до інсуліну, гальмує розвиток абдомінального ожиріння в щурів зі спонтанним ЦД 2 типу, знижує гіпертригліцеридемію в щурів зі стрептозотоциновим діабетом, підвищує рівень відновленого глутатіону в ізольованих гепатоцитах. Клінічні дослідження показали, що таурин запобігає розвитку інсулінорезистентності та дисфункції панкреатичних $\beta$-клітин, що індуковані підвищеним рівнем вільних жирних кислот у чоловіків із надмірною масою тіла. Сьогодні є велика кількість експериментальних даних про позитивні результати застосування таурину для запобігання розвитку діабетичних ускладнень, спричинених тривалою некомпенсованою гіперглікемією, зокрема діабетичної нефропатії.

Завдяки своїм антиоксидантним властивостям, таурин зменшує апоптоз ендотеліальних клітин, індукований вільними радикалами, відновлює проникність мембран і запобігає клітинним ушкодженням, пов'язаним зі збільшенням внутрішньоклітинного току Са2+. Антидіабетичні властивості таурину можуть реалізовуватися за рахунок 4 основних механізмів дії: антиоксидантної активності, протизапальних ефектів, осморегуляторної активності, впливу на глюкозний гомеостаз.

Експериментальні дані широкого спектра антидіабетичних властивостей таурину свідчать про доцільність його вивчення в рамках подальших клінічних випробувань як додаткового засобу комплексної фармакотерапії ЦД та його ускладнень. 


\section{Висновки}

Біологічно активні компоненти лікарських рослин, можуть проявляти цукрознижувальний ефект, який впливатиме на активність ключових ферментів обміну вуглеводів, транспорт глюкози та функції рецептора до інсуліну, порушення яких відіграють важливу роль в патогенезі ЦД.

1. Асфандиярова Н. С. Смертность при сахарном диабете 2 типа. Сахарный диабет. 2015. № 18 (4). C. 12-21.

2. Беляков К. В. Фитотерапия сахарного диабета. Consilium privisorum. 2007. № 6 (50). С. $26-27$.

3. Бильченко А. В. Сахарный диабет и сердечно-сосудистые заболевания. Ліки України. 2009. № 4. C. $78-81$.

4. Блецкан М. М., Свистак В. В. Особливості застосування фітотерапії при ожирінні. Украӥна. Здоров’я наиіï. 2018. С. 5-8

5. Боднар П. М. Ендокринологія. Вінниця : Нова книга, 2010. 464 с.

6. Боднар П. М., Михальчишин Г. П. Актуальні питання діагностики та лікування цукрового діабету. Мистецтвво лікування. 2003. № 1. С. 51-55.

7. Власенко М. В. Бігуаніди в лікуванні цукрового діабету 2-го типу: стандарти та інновації. Міжнар. ендокринол. журнал. 2009. № 3. С. 41-44.

8. Ганзий Т. В. Новые классы гипогликемических средств в лечении сахарного диабета 2-го типа. Теоретична і експериментальна медицина. 2014. № 3 (52). С. 47-52.

9. Горохова Т. А., Марсов М. Г., Солєннікова С. М., Бєлоногова В. Д. Макро- і мікроелементи брусниці, буяхів, чорниці та мучниці. Фармац. журн. 2004. № 3. С. 102-104.

10. Гринкевич Н. И. Ладыгина А. Е. Фармакогнозия. Атлас. Медицина. 2009. 320 с.

11. Демченко Д. В. Сравнительное фитохимическое исследование побегов и листьев черники обыкновенной (Vaccinium myrtillus L.). Растительные ресурсы. 2006. № 11. С. 25.

12. Джафарова Р. Э. Исследование гипогликемического действия некоторых лекарственных растений, содержащих флавоноиды. Проблемы физиол. и биохимии. 2008. Т. 26. С. 237-248.

13. Зворська О. 3., Грошовий Т. А. Чорниця звичайна (Vaccinum myrtillus L.) - перспективна сировина для одержання лікарських засобів. Pharmaceutical. 2009. № 3. С. 29-33.

14. Казека Г. Р. Метаболический синдром: Врачебный практикум. Новосибирск, 2002. 50 с.

15. Каминский А. В. Место препаратов сульфонилмочевины в терапии сахарного диабета 2-го типа. Міжнародний ендокринологічний журнал. 2011. № 2 (34). С. 59-62.

16. Катеренчук В. І. Сучасна терапія цукрового діабету 2-го типу з використанням препаратів компанії «Фармак». Сімейна медицина. 2009. № 4. С. 110-114.

17. Квасова Т. М. Влияние препаратов сбора Арфазетин на течение экспериментального сахарного диабета у крыс. Врач-аспирант. 2011. № 5.1 (48). С. 157-162.

18. Кирилюк М. Л., Гавловський О. Д. Сучасні клініко-патофізіологічні аспекти цукрового діабету 2 типу. Інтегративна Антропологія. 2009. № 2 (14). С. 40-44.

19. Кіхтяк О. П. Механізми розвитку інсулінорезистентності та їі мішені. Украӥнський медичний Часопис. 2013.5 (97). С. 99-102.

20. Клиническая фармакология : учебник / под ред. В. Г. Кукеса. М. :«Гэотар -Медицина», 2004.917 с.

21. Клінічна фармакологія: підруч. для студ. вищ. навч. закл. / С. В. Нальотов, І. А. Зупанець, Т. Д. Бахтєєва та ін. Х. : Вид-во НФаУ : Золоті сторінки, 2007. Т. 1.348 с.

22. Ковальов В. М., Павлій О. І., Ісакова Т. І. Фармакогнозія з основами біохімії рослин. Харків : Прапор, 2000. 556 с.

23. Количев І. О., Краснікова Т. О., Загайко А. Л., Кошовий О. М. Дослідження органічних кислот спиртового екстракту з листя чорниці звичайної. Укр. біофармац. журн. 2016. № 1. С. 55-57.

24. Количев I. О., Краснікова Т. О., Кошовий О. М. Дослідження амінокислотного складу спиртового екстракту з листя чорниці звичайної. Вісник фармації. 2016. № 2. С. 12-15.

25. Кондрацкая И. Н. Сахарный диабет 2 типа. Критерии постановки диагноза. Принципы первичной антигипергликемической терапии. Проблеми ендокринної патологіï. 2015. № 2. С. 119-122.

26. Корсун В. Ф., Трумпе Т. Е., Корсун Е. В., Ершов Н. В., Огренич Н. А. Фитотерапия против диабета. М: Центрполиграф, 2015. 352 с.

27. Лекарственное растительное сырье. Фармакогнозия: учебное пособие / под. ред. Г. П. Яковлева, К. Ф. Блиновой. СПб. : СпецЛит., 2004. С. 442-443.

28. Лукашів О. Я. Використання біологічно активних речовин для профілактики і регуляції метаболізму при цукровому діабеті. 2018. С. 119-122. 
29. Марчишин С. М., Олещук О. М., Савич А. О. Визначення фармакологічної активності нового рослинного збору з антидіабетичною дією. Фітотерапія: часопис. 2015. №. 2. С. 35-40.

30. Маршанова Л. М. Исследование состава и разработка биотехнологии получения биологически активных концентратов черники обыкновенной - Vaccinium myrtillus L.: автореф. канд. биол. наук: 03.00.23. Ставрополь, 2006. 27 с.

31. Михайленко О. Ю. Сучасна терапія цукрового діабету 2-го типу з використанням представника групи препаратів сульфонілсечовини - гліклазиду сповільненого вивільнення виробництва ПАТ «Фармак». Международный эндокринологический журнал. 2015. Т. 2, № 66. С. 52-56.

32. Новіков В. П., Конечна Р. Т., Стадницька Н. С. Фітозасоби в лікуванні цукрового діабету: (огляд літератури). Фітотерапія. Часопис. 2007. № 3. С. 9-15.

33. Новое направление в терапии сахарного диабета 2-го типа: какие возможности нам предоставляет виктоза? Міжнародний ендокринологічний журнал. 2012. № 3 (43). С. 61-65.

34. Остапів Р. Д., Кисців О. С., Манько В. В. Вплив тривалого перорального введення таурину на фізіологічні показники щурів. Вісник Львівського університету. Сер. біол. 2015. Вип. 69. С. 247-255.

\section{References}

1. Asfandiiarova N. S. Smertnost' pri sakharnom diabete 2 tipa. Sakharnyy diabet. 2015 . No 18 (4). S. 12-21 (in Russian).

2. Beliakov K. V. Fitoterapiia sakharnogo diabeta. Consilium privisorum. 2007. No 6 (50). S. 26-27 (in Russian).

3. Bil'chenko A. V. Sakharnyy diabet i serdechno-sosudistye zabolevaniia. Liki Ukraïni. 2009. No 4. S. 78-81 (in Russian).

4. Bletskan M. M., Svystak V. V. Osoblyvosti zastosuvannia fitoterapii pry ozhyrinni. Ukraina. Zdorov'ia natsii. 2018. S. 5-8 (in Ukrainian).

5. Bodnar P. M. Endokrynolohiia. Vinnytsia. Nova knyha. 2010. 464 s (in Ukrainian).

6. Bodnar P. M., Mykhal'chyshyn H. P. Aktual'ni pytannia diahnostyky ta likuvannia tsukrovoho diabetu. Mystetstvo likuvannia. 2003. No 1. S. 51-55 (in Ukrainian).

7. Vlasenko M. V. Bihuanidy v likuvanni tsukrovoho diabetu 2-ho typu: standarty ta innovatsii. Mizhnar. endokrynol. zhurnal. 2009. No 3. S. 41-44 (in Ukrainian).

8. Ganziy T. V. Novye klassy gipoglikemicheskikh sredstv v lechenii sakharnogo diabeta 2-go tipa. Teoretichna i eksperimental'na meditsina. 2014. No 3 (52). C. 47-52 (in Russian).

9. Horokhova T. A., Marsov M. H., Soliennikova S. M., Bielonohova V. D. Makro- i mikroelementy brusnytsi, buiakhiv, chornytsi ta muchnytsi Farmats. zhurn. 2004. No 3. S. 102-104 (in Ukrainian).

10. Grinkevich N. I. Ladygina A. E. Farmakognoziia. Atlas Meditsina. 2009. 320 s (in Russian).

11. Demchenko D. V. Sravnitel'noe fitokhimicheskoe issledovanie pobegov i list'ev cherniki obyknovennoy (Vaccinium myrtillus L.). Rastitel'nye resursy. 2006. No 11. S. 25(in Russian).

12. Dzhafarova R. E. Issledovanie gipoglikemicheskogo deystviia nekotorykh lekarstvennykh rasteniy, soderzhashchikh flavonoidy. Problemy fiziol. i biokhimii. 2008. T. 26. S. 237-248 (in Russian).

13. Zvors'ka O. Z., Hroshovyy T. A. Chornytsia zvychayna (Vaccinum myrtillus L.) - perspektyvna syrovyna dlia oderzhannia likars'kykh zasobiv. Pharmaceutical. 2009. No 3. S. 29-33 (in Ukrainian).

14. Kazeka G. R. Metabolicheskiy sindrom: Vrachebnyy praktikum. Novosibirsk, 2002. 50 s.

15. Kaminskiy A. V. Mesto preparatov sul'fonilmocheviny $\mathrm{v}$ terapii sakharnogo diabeta 2-go tipa. Mizhnarodniy endokrinologichniy zhurnal. 2011. No 2 (34). S. 59-62 (in Russian).

16. Katerenchuk V. I. Suchasna terapiia tsukrovoho diabetu 2-ho typu z vykorystanniam preparativ kompanii «Farmak». Simeyna medytsyna. 2009. No 4. S. 110-114 (in Ukrainian) (in Russian).

17. Kvasova T. M. Vliianie preparatov sbora Arfazetin na techenie eksperimental'nogo sakharnogo diabeta u krys. Vrach-aspirant. 2011. No 5.1 (48). S. 157-162 (in Russian).

18. Kyryliuk M. L., Havlovs'kyy O. D. Suchasni kliniko-patofiziolohichni aspekty tsukrovoho diabetu 2 typu. Intehratyvna Antropolohiia. 2009. No 2 (14). S. 40-44 (in Ukrainian).

19. Kikhtiak O. P. Mekhanizmy rozvytku insulinorezystentnosti ta ii misheni. Ukrains'kyy medychnyy Chasopys. 2013.5 (97). S. 99-102 (in Russian).

20. Klinicheskaia farmakologiia : uchebnik / pod red. V. G. Kukesa. M. :«Geotar-Meditsina», 2004. 917 s (in Russian).

21. Klinichna farmakolohiia: pidruch. dlia stud. vyshch. navch. zakl. / S. V. Nal'otov, I. A. Zupanets', T. D. Bakhtieieva [ta in.]. Kh. : Vyd-vo NFaU : Zoloti storinky, 2007. T. 1. $348 \mathrm{~s}$ (in Ukrainian).

22. Koval'ov V. M., Pavliy O. I., Isakova T. I. Farmakohnoziia z osnovamy biokhimii roslyn. Kharkiv, Prapor, 2000. $556 \mathrm{~s}$ (in Ukrainian). 
23. Kolychev I. O., Krasnikova T. O., Zahayko A. L., Koshovyy O. M. Doslidzhennia orhanichnykh kyslot spyrtovoho ekstraktu z lystia chornytsi zvychaynoi. Ukr. biofarmats. zhurn. 2016. No 1. S. $55-57$ (in Ukrainian).

24. Kolychev I. O., Krasnikova T. O., Koshovyy O. M. Doslidzhennia aminokyslotnoho skladu spyrtovoho ekstraktu z lystia chornytsi zvychaynoi. Visnyk farmatsii. 2016. No 2. S. 12-15 (in Ukrainian).

25. Kondratskaia I. N. Sakharnyy diabet 2 tipa. Kriterii postanovki diagnoza. Printsipy pervichnoy antigiperglikemicheskoy terapii. Problemi endokrinnoï patologiï. 2015. No 2. S. 119-122 (in Russian).

26. Korsun V. F., Trumpe T. E., Korsun E. V., Ershov N. V., Ogrenich N. A. Fitoterapiia protiv diabeta. M: Tsentrpoligraf, 2015. 352 s (in Russian).

27. Lekarstvennoe rastitel'noe syr'e. Farmakognoziia: uchebnoe posobie / pod. red. G. P. Iakovleva, K. F. Blinovoy. SPb.: SpetsLit., 2004. S. 442-443 (in Russian).

28. Lukashiv O. Ya. Vykorystannia biolohichno aktyvnykh rechovyn dlia profilaktyky i rehuliatsii metabolizmu pry tsukrovomu diabeti. 2018. S. 119-122 (in Ukrainian).

29. Marchyshyn S. M., Oleshchuk O. M., Savych A. O. Vyznachennia farmakolohichnoi aktyvnosti novoho roslynnoho zboru z antydiabetychnoiu diieiu. Fitoterapiia chasopys. 2015. No. 2. S. 35-40 (in Ukrainian).

30. Marshanova L. M. Issledovanie sostava i razrabotka biotekhnologii polucheniia biologicheski aktivnykh kontsentratov cherniki obyknovennoy - Vaccinium myrtillus L.: avtoref. kand. biol. nauk: 03.00.23. / L. M. Marshanova. Stavropol', 2006. 27 s (in Russian).

31. Mykhaylenko O. Yu. Suchasna terapiia tsukrovoho diabetu 2-ho typu z vykorystanniam predstavnyka hrupy preparativ sul'fonilsechovyny - hliklazydu spovil'nenoho vyvil'nennia vyrobnytstva PAT «Farmak». Mezhdunarodnыy эndokrynolohycheskyy zhurnal. 2015. T. 2, No 66. S. 52-56 (in Ukrainian).

32. Novikov V. P., Konechna R. T., Stadnyts'ka N. Ie. Fitozasoby v likuvanni tsukrovoho diabetu: (ohliad literatury) Fitoterapiia. Chasopys. 2007. No 3. S. 9-15 (in Ukrainian).

33. Novoe napravlenie $\mathrm{v}$ terapii sakharnogo diabeta 2-go tipa: kakie vozmozhnosti nam predostavliaet viktoza? Mizhnarodniy endokrinologichniy zhurnal. 2012. No 3 (43). S. 61-65 (in Russian).

34. Ostapiv R. D., Kystsiv O. S., Man'ko V. V. Vplyv tryvaloho peroral'noho vvedennia taurynu na fiziolohichni pokaznyky shchuriv. Visnyk L'vivs'koho universytetu. Ser. biol. 2015. Vyp. 69. S. 247-255 (in Ukrainian).

\author{
${ }^{1}$ Kh. I. Kurylo, ${ }^{1}$ A. S. Volska, ${ }^{1}$ I. M. Klishch, ${ }^{2}$ B. V. Zablotskyi \\ ${ }^{1}$ I.Horbachevsky Ternopil State Medical University, Ukraine \\ ${ }^{2}$ Ternopil V. Hnatiuk National Pedagogical University, Ukraine
}

\title{
MODERN APPROACHES TO THE PHARMACOLOGICAL CORRECTION OF METABOLIC CHANGES IN DIABETES MELLITUS TYPE 2
}

Diabetes mellitus is caused by one of the largest medical and social problems in Ukraine, because it causes a high risk of invasive disease. According to the WHO data, the number of patients is rising and people of varying age groups become ill, which causes an increase in the incidence of 3 to 4 pauses and the overall life expectancy of $20-30 \%$.

Pathogenesis of diabetes mellitus and enclosure, require the extraction of drugs for prophylaxis and treatment with late pharmacological effects. One of these is a herbal remedy.

Analysis and systematization of the literature on metabolitotropic effects and substantiation of the use of new goat's-rue, blueberry and taurine phytocompositions for the correction of metabolic changes in diabetes type 2 were carried out.

The methods of information search, analysis of literature on the medicinal plants with hypoglycemic action were used.

The literary resources on pharmacological correction of metabolic changes in diabetes type 2 deal with natural herbs and amino acids that possess hypoglycemic action and can be used with therapeutic and prophylactic measure in patients with type 2 diabetes.

In type 2 diabetes mellitus significant anticytolytic, detoxifying and antioxidant properties of phytocompositions were confirmed.

It is known that in hyperglycemia and insulin resistance that occur at type 2 diabetes mellitus end products of glycosylation and glucose autooxidation are formed, which is accompanied by the activation of lipid peroxidation and the formation of a large number of free radicals.

It is known that one of the basic mechanisms for the development of insulin resistance, diabetes mellitus and specific diabetic angiopathies is oxidative stress. 
One of the major pathogenetic factors in the development and course of type 2 diabetes mellitus is metabolic syndrome. It has been established that correction using both investigated phytocompositions and reference phytopreparation with different efficiency prevented the development of metabolic changes in metabolic syndrome.

Biologically active components of medicinal plants, may show hypoglycemic effect which will influence the activity of the enzymes, glucose transcription and the function of the peptide to the incyline, the processes which play an important role in the pathogenesis of diabetes.

Key words: diabetes mellitus, goat's-rue, blueberry, taurine, hypoglycemic activity.

Надійшла 26.08.2019. 